\title{
Op zoek naar de tweede helix
}

\author{
OVER HET MILIEUBEGRIP EN DE ONTRAFELING VAN HET \\ DNA VAN DE NEDERLANDSE FILMCULTUUR
}

\begin{abstract}
In respect to the Cinema Context database, Karel Dibbets argued that basic data about the Who, What, Where and When of film exhibition and distribution represent the genes within the DNA of film culture. Building upon this imaginative use of the DNA-metaphor, this article seeks to develop the idea that the Cinema Context model contains only one of the two helixes of film culture's DNA. In biochemistry, double helix is the term used to describe the structure of DNA, which consists of two spiral chains. The question is: what exactly constitutes the second helix of film culture? And what are the implications of the double helix structure for New Cinema Historiography? We argue that a wide range of data about audience practices and their everyday lives (from statistics about religious affiliation and population density to personal memories about cinemagoing) form the building blocks of the second helix and that these data need to be studied in interrelationship with each other. To bring focus into such research, we propose to use the concept of milieu as a heuristic tool and we explore its potential with a case study about moviegoing practices among Dutch Orthodox Protestants (Gereformeerden) in the Netherlands in the immediate post-war era (i945-early i960s).
\end{abstract}

TREFWOORDEN: Nederlandse filmcultuur; milieubegrip; Gereformeerden; historiografie; New Cinema History

Voor filmhistorici die zich de afgelopen tien jaar in het kader van de New Cinema History richtten op de geschiedenis van de Nederlandse filmcultuur, stuurde één publicatie in hoge mate hun onderzoeksagenda en onderlinge discussies: "Het taboe van de Nederlandse filmcultuur. Neutraal in een verzuild land" van Karel Dibbets. In dit artikel, dat verscheen in het Cinema in Context nummer van het Tijdschrift voor mediageschiedenis, zet Dibbets een prikkelende these uiteen. ${ }^{\text {I }}$ De acceptatie en populariteit van het medium film, zo stelt hij, bleef in ons land lange tijd achter bij die in omringende Europese landen, omdat de bioscoop niet geïntegreerd raakte in de structuren van de alom tegenwoordige verzuiling, waarin andere massamedia wel een plek kregen. Vanuit sommige zuilen en in het bijzonder vanuit de katholieke zuil werd aanvankelijk wel geprobeerd om de bioscoop in te kapselen in die structuren, maar tevergeefs. Het Nederlandse filmbedrijf had zich er met succes tegen verzet. En moest daarvoor vervolgens een zware tol betalen, omdat zowel gemeentelijke als landelijke autoriteiten de ontplooiing van de bioscoop stevig aan banden legden. Dat deden ze onder het motto dat deze amusementsvorm 
een moreel verdacht buitenbeentje en dus een maatschappelijk gevaar was. Dibbets spreekt in dit verband over een ideologisch kartel van politici en bestuurders die zich aaneensloten - de confessionelen onder hen het fanatiekst - om het bioscoopbedrijf en de commerciële filmcultuur in Nederland klein te houden. De branche reageerde daar volgens Dibbets op met de vorming van een economisch kartel, geïnstitutionaliseerd in de Nederlandse Bioscoopbond, dat een beleid voerde dat grosso modo meeging in de politiek-bestuurlijke inzet van overheden om de ontwikkeling van de bioscoop binnen de Nederlandse samenleving te beperken. In ruil daarvoor kreeg de bond van de overheid de speelruimte om door vergaande interne regulering van de markt de rentabiliteit van de bedrijfstak veilig te stellen, hoe lastig de bemoeizuchtige autoriteiten het haar soms ook maakten. ${ }^{2}$

Zoals gezegd: een prikkelende these. Niet alleen vanwege zijn inhoudelijke strekking, die de verlokkingen van een samenzweringstheorie in zich draagt, maar ook omdat Dibbets ter onderbouwing niet zo heel veel empirisch materiaal aandroeg. Althans, niet binnen het verband van een op bronnen gefundeerde argumentatie. Wel verzamelde hij een enorme hoeveelheid onbewerkte gegevens (raw data) in zijn Cinema Context database. Daarmee zou volgens Dibbets op den duur de empirische onderbouwing van zijn these te genereren moeten zijn; een kwestie van het blootleggen van de patronen en samenhangen tussen de opgeslagen data. Zoals Karel Dibbets het zelf vaak zei: aan de hand van Cinema Context is het DNA van de Nederlandse filmcultuur te ontleden. Maar dat was en is toekomstmuziek; het 'bewijs' voor Dibbets' these is nog niet geleverd.

In het licht van het voorgaande verbaast het niet dat het streven naar empirische toetsing van Dibbets' these als een rode draad door de recente filmgeschiedschrijving over de vooroorlogse Nederlandse filmcultuur loopt. Opvallend daarbij is dat de analyse van gegevens uit de Cinema Context database hierbij (nog) geen vooraanstaande rol heeft gespeeld. Wat je in de betreffende publicaties wel aantreft, is een herhaald pleidooi om het door Dibbets geopperde verklaringsmodel complexer te maken. Naast de verzuilingsproblematiek, zouden ook andere factoren moeten worden meegewogen, zoals klasse en de typisch Nederlandse huiselijkheidscultuur. ${ }^{3}$ Met zo'n veelzijdiger insteek zou het inzicht in de dynamiek van de Nederlandse filmcultuur verder te verrijken zijn.

Tot de pleitbezorgers van een uitgebreider perspectief behoren wij ook zelf. En wat volgens ons bij de ontwikkeling ervan kan helpen, is een concept dat zowel in heuristisch als in interpretatief opzicht het onderzoek richt op het samenspel van factoren dat op het alledaagse niveau de filmconsumptie van uiteenlopende groepen Nederlanders vorm gaf en geeft. Op het niveau dus, waarop het referentiekader van de verzuiling zijn concrete doorwerking kreeg op het dagelijks leven en handelingspraktijken van mensen. Het niveau óók waarop hun klassenachtergrond, hun huismusserigheid en wie weet nog allerlei andere factoren zich praktisch uitten. Niet elk voor zich, maar steeds in wisselwerking met elkaar. Dat ingewikkelde proces moeten we nader in kaart brengen en daarvoor hebben we een dergelijk concept nodig.

Als een veelbelovende kandidaat voor die rol, stellen wij het begrip milieu voor. Hieronder lichten wij eerst toe hoe het begrip in andere vakgebieden is ingezet en hoe wij het willen gebruiken binnen de New Cinema History. Daarna verkennen we wat de inzet van het 
milieubegrip zou kunnen opleveren aan de hand van een kleine casestudy over bioscoopbezoek onder Nederlandse gereformeerden. In de afsluitende paragraaf preciseren we de relatie tussen het type onderzoek dat wij bepleiten en het Cinema Context project van Karel Dibbets.

\section{Het begrip milieu en de inzetbaarheid binnen New Cinema History}

In de hedendaagse wetenschappelijke wereld vindt het milieubegrip vooral toepassing in de sociologie en het wordt gebruikt door onderzoekers die onze fysieke leefomgeving bestuderen zoals geografen, ecologen en biologen. Stefan Hradil, één van de meest gezaghebbende pleitbezorgers van het begrip binnen de sociologie, definieert een sociaal milieu als 'een groepering van mensen, die in vergelijkbare omstandigheden leven, op een vergelijkbare manier denken en zo het gedrag van individuen op een vergelijkbare manier vormen.' ${ }^{4}$ De 'vergelijkbare omstandigheden' kunnen bij het concreet beschrijven van een specifiek milieu een heel diverse invulling krijgen: van sociaaleconomische omstandigheden (het daklozenmilieu), het behoren tot formele en informele groeperingen zoals kerkgemeenschappen (het katholieke milieu), migrantengemeenschappen (het Turks-Nederlandse milieu), of beroepsgroepen (het toneelspelersmilieu, het criminele milieu), tot scholingsniveaus (het intellectuele milieu) en geografisch specifieke leefomgevingen (het grootstedelijk milieu). Bovendien kan de combinatie van omstandigheden waarmee een specifiek sociaal milieu zich laat definiëren van geval tot geval variëren en is er hierdoor ook overlap mogelijk tussen sociale milieus. De grenzen ertussen zijn vloeibaar. Door de tijd heen kunnen milieus sterker of zwakker worden qua interne samenhang en herkenbaarheid, of zelfs volledig verdwijnen. Natuurlijk kunnen zich ook nieuwe milieus formeren. ${ }^{5}$ Het milieubegrip biedt dus qua invulling een enorme elasticiteit, waarbij het er bij de analyse van concrete sociale milieus steeds om gaat vast te stellen welke combinaties van omstandigheden meespelen en hoe deze doorwerken in het denken, het voelen en het gedrag van de mensen die binnen dat specifieke milieu te plaatsen zijn. Die elasticiteit en daarmee het vermogen om heel uiteenlopende combinaties van factoren en hun onderlinge dynamiek in beschouwing te nemen, was precies wat sociologen in het milieubegrip zochten. Ze kregen daar vanaf de tweede helft van de jaren zeventig behoefte aan, omdat concepten als klasse en stand, die eerder in zwang waren om het denken en handelen van groepen mensen te verklaren, te beperkt en te star bleken als ze niet in samenhang met andere factoren werden ingezet. ${ }^{6}$

Binnen de geschiedwetenschap heeft het sociologische milieubegrip eveneens weerklank gevonden, in het bijzonder in het toenmalige West-Duitsland. Vanaf het begin van de jaren tachtig verwierf het daar faam als handvat voor sociaalhistorisch onderzoek naar het binnenlands verzet tegen het Nationaal Socialisme. Kenmerkend voor de wijze waarop de West-Duitse sociaal-historici het begrip interpreteerden, is dat zij een breder aantal factoren in ogenschouw namen bij het analyseren van specifieke milieus dan hun collega's van sociologie. Vernieuwend was eveneens dat deze historici de milieus koppelden aan gemeenschappen met een kleinere, lokaal of regionaal begrensde leefwereld. Dat deed bijvoorbeeld Klaus Tenfelde in zijn beroemde studie over politieke radicalisering en anti-nazisme onder de arbeidersbevolking 
van Penzberg, een mijnstadje in Zuid-Beieren.7 Met de groeiende populariteit van de cultuurgeschiedenis in de jaren negentig verloor de sociale geschiedenis terrein en raakte het milieubegrip uit de mode, hoe vruchtbaar de inzet ervan voordien ook geweest was. Het begrippenapparaat verschoof naar termen als habitus en levensstijl, overigens zonder dat daar fundamentele empirische of theoretische argumenten tégen het gebruik van het milieubegrip aan ten grondslag lagen. Buiten de kring van vakhistorici zijn er zelfs sociale wetenschappers die al deze begrippen gewoon met elkaar combineren in één perspectief. ${ }^{8}$ Historici neigen daar helaas tot op heden minder toe. 9

Voor de inzet van het milieubegrip binnen de New Cinema History is de interpretatie van het milieubegrip door sociologen en historici het meest relevant. Dat neemt niet weg dat het gebruik van het begrip ter verwijzing naar de fysieke leefomgeving en de daardoor geschapen materiële condities ons erop attendeert dat ook deze contexten een rol spelen in de manier waarop sociale groepen omgaan met film. Denk aan gebouwen en hun interieurs, de geografische situering daarvan in stad of dorp, aan de infrastructuur (weg, spoor) die het mogelijk maakt dat films rouleren en mensen de plaatsen bereiken waar films worden vertoond. Aandacht voor dergelijke materiële condities van distributie en consumptie is de afgelopen jaren dankzij de spatial turn binnen media studies al sterk toegenomen, ook binnen de New Cinema History. ${ }^{10}$

In de flexibiliteit van het milieubegrip schuilt tegelijkertijd wel een gevaar, namelijk dat we het met een eindeloze hoeveelheid empirische gegevens gaan 'vullen', zonder dat daar nog systematiek of structuur in te herkennen is. Hierdoor zou het onmogelijk kunnen worden steekhoudende vergelijkingen te trekken tussen milieus. Terwijl zulk comparatief onderzoek nu juist zo belangrijk is om beter inzicht te krijgen in de eigenheid van de Nederlandse filmcultuur en de onderlinge dynamiek van de daarbinnen te onderscheiden 'subculturen'. ${ }^{\text {II }}$ In dit licht is het nodig om wat meer sturing te geven aan de manier waarop we het milieuconcept concreet inzetten. En dan dient zich de vraag aan: in welke richting willen we door het begrip gestuurd worden?

Om daar een antwoord op te kunnen geven moet helder zijn wat het uiteindelijke doel is van ons onderzoek. Willen we door studie van een milieu begrijpen hoe een bepaalde groep mensen participeerde in de filmcultuur als onderdeel van hun vrijetijdsbesteding? Of is de bestudering van participatie in de filmcultuur eerder onderdeel van een project dat beoogt een bepaald milieu in zijn geheel beter te doorgronden? De eerste insteek - zo zou je kunnen zeggen - is die van een onderzoeker die zichzelf primair ziet als een filmhistoricus. De tweede is veel meer die van een sociaal historicus of algemeen cultuurhistoricus. Het is echter beter de twee invalshoeken niet al te scherp tegenover elkaar te zetten. Bij elk concreet onderzoek is een mix van beide denkbaar, waarbij per casus - en vooral: per onderzoeker - het relatieve gewicht van elk van de twee perspectieven kan variëren. Wat onszelf betreft ligt het accent doorgaans bij het tweede perspectief en bestuderen wij filmcultuur als ingang op bredere, sociaal- en cultuurhistorische vraagstukken. ${ }^{\mathrm{I2}}$ Maar zelfs als het accent ligt op het eerste perspectief, dan blijft overeind dat om de filmcultuur van een bepaald milieu te begrijpen, serieus aandacht moet worden besteed aan milieukenmerken die niet meer evident herkenbaar zijn 
als onderdeel van de filmcultuur. Pas wanneer er sprake is van een brede contextualisering, kan de inzet van het milieubegrip meerwaarde bieden voor de filmhistoricus. Hoe ver je als filmhistoricus moet gaan met het doorspitten van de bredere maatschappelijke en economische context, valt niet op voorhand te zeggen en zal sterk afhangen van de concrete vraag die een onderzoek stuurt. ${ }^{13}$ Belangrijk is vooral er niet al op voorhand te terughoudend in te zijn. Vooralsnog is binnen de New Cinema History het probleem eerder een tekort dan een teveel aan serieuze contextualisering.

Hoe laat het onderzoek naar de filmcultuur binnen een bepaald milieu zich zodanig inrichten dat het voldoende focus behoudt en praktisch uitvoerbaar is? Wij stellen voor dit te doen aan de hand van een vijftal invalshoeken, die onderling met elkaar verweven zijn en zo zijn gekozen dat ze het onderzoek in eerste instantie laten beginnen bij empirische fenomenen die binnen het domein van de filmcultuur in engere zin liggen. Dat moet ze bruikbaar maken voor een breed scala onderzoekers, onafhankelijk of ze werken vanuit een filmhistorische interesse of meer vanuit een sociaal- of cultuurhistorische insteek. De vijf invalshoeken zijn gericht op:

I. De verhalen die binnen of over de onderzochte populatie met betrekking tot film, bioscoop en vrijetijdsbesteding in omloop zijn. Daar horen verhalen bij die geladen zijn met een of andere vorm van gezag, bijvoorbeeld omdat ze in omloop worden gebracht door formele of informele leiders, de overheid, onderzoeksinstituten, en andere autoriteiten in de breedst mogelijk zin van het woord. Maar ook verhalen 'van onderop' horen erbij, verhalen uit en over het dagelijks leven van mensen behorend tot de onderzochte populatie, waarvan de strekking soms zal onderschrijven, soms juist zal ondergraven wat de gezaghebbende verhalen willen doen geloven.

2. De handelingspraktijken die verbonden zijn met de binnen en over een populatie circulerende verhalen over film, bioscoop en vrijetijdsbesteding. Praktijken die overeenkomen met wat de verhalen vertellen, praktijken die daarmee op gespannen voet staan, en praktijken waarvan het bestaan slechts zijdelings of indirect te documenteren is, omdat ze in de roulerende verhalen niet of nauwelijks expliciet worden genoemd.

3. De institutionele en organisatorische kaders waarin de onder I en 2 bedoelde verhalen en praktijken zijn gesitueerd. Tot die kaders behoren bijvoorbeeld bedrijven in de filmsector, maar ook filmclubs, brancheorganisaties, censuurinstanties en levensbeschouwelijke instellingen. Lang niet altijd zijn dit instituties die er zelf een (film-)consumptiepraktijk op nahouden. Maar ze sturen wèl mede het handelen van de onderzochte populatie en dus is het belangrijk ze mee te nemen in de analyse.

4. Fysieke infrastructuren die de sociaal-culturele praktijken en het consumptiegedrag van de onderzochte populatie beïnvloeden. Denk aan de zalen en gebouwen waarin mensen films gaan zien (niet altijd zijn dat officiële bioscopen!), maar denk ook aan het wegennetwerk en de verkeersmiddelen die worden gebruikt om zowel films als publiek van en naar die vertoningsplaatsen te transporteren. Eveneens relevant zijn de grotere geografische constellaties waarin vertoningslocaties functioneren, bijvoorbeeld uitgaansgebieden binnen steden, of de 
kleine steden en grotere dorpen die als verzorgingskern dienen voor de landelijke gebieden eromheen.

5. Bij ons laatste aandachtspunt gaat het om iets dat zich altijd voordoet als er verhalen worden verteld, praktijken worden uitgevoerd, institutionele kaders werkzaam zijn en fysieke infrastructuren worden ingezet: het besteden of verbruiken van tijd (nader te karakteriseren in termen van duur, tempo, ritme, versnelling, vertraging, et cetera). ${ }^{\mathrm{I}}$

Dit lijstje van vijf invalshoeken is geen keurslijf. Het geeft richting en focus aan het empirisch onderzoek, maar er moet verder pragmatisch mee worden omgesprongen. Er zullen in elk onderzoek naar een milieu nog andere aspecten een rol gaan spelen dan in dit lijstje zijn opgenomen. Denk aan milieu-specifieke omgevingsfactoren zoals bijvoorbeeld de impact van het wonen op een eiland, of bij migranten de culturele binding met het moederland. Verdere verbreding van het onderzoeksperspectief zal altijd noodzakelijk zijn. Maar zolang de bovengenoemde vijf invalshoeken een plek houden in specifieke case studies, is gegarandeerd dat de uitkomsten ervan bruikbaar zijn voor vergelijkend onderzoek. En vergelijkend onderzoek is noodzakelijk als we de Nederlandse filmcultuur in haar diversiteit én uniciteit willen doorgronden.

Om te verkennen wat de voorgestelde onderzoeksaanpak kan opleveren, presenteren we hieronder een kleine casestudy over de filmconsumptie en vrijetijdsbesteding van de leden van de Gereformeerde Kerken in Nederland (GKN), of - zoals ze meestal worden genoemd - de 'gewoon gereformeerden.' Zij maakten deel uit van de protestants-christelijke zuil, waarbinnen ze de op één na grootste gezindte vormden - na de Nederlandse Hervormde Kerk (NHK). Daarnaast herbergde de protestants-christelijke zuil nog een behoorlijk aantal kleinere kerkgenootschappen, die zich deels óók gereformeerd noemden, zoals de gereformeerd vrijgemaakten en de leden van de Gereformeerde Bond. De meeste van deze religieuze splintergenootschappen waren streng orthodox in hun geloofsbeleving. ${ }^{15}$

Wat het tijdsbestek betreft, richt onze casestudy zich op de lange jaren vijftig (I945 tot begin jaren zestig). We kiezen voor deze periode omdat toen veel Nederlanders regelmatig naar de bioscoop gingen - het gemiddelde schommelde rond de zes keer per jaar, wat uitzonderlijk was voor Nederlandse begrippen. ${ }^{16}$ Steeds meer Nederlanders namen actief deel aan de filmcultuur, ook groepen die voor de Tweede Wereldoorlog maar zeer zelden of helemaal niet in de bioscoop te vinden waren, zoals de leden van de GKN. ${ }^{77}$ De gekozen periode is echter niet alleen hierom interessant. Ook op het gebied van de verzuiling kwam er een bijzondere dynamiek op gang, die in de literatuur is gekarakteriseerd als een 'dubbele paradox van ver- en ontzuiling. ${ }^{{ }^{18}}$ In sommige opzichten vond een intensivering plaats van de verzuiling, in andere opzichten manifesteerde zich tegelijkertijd een neiging naar ontzuiling. ${ }^{\text {I9 }}$

De bronnenbasis voor onze casestudy is samengesteld uit secundaire literatuur, diverse onderzoeksrapporten uit de periode zelf en een klein corpus van via oral history verkregen gegevens, dat de afgelopen jaren onder onze eigen verantwoordelijkheid tot stand werd gebracht. Daarnaast zijn we zelf geïnteresseerd in filmconsumptie onder gereformeerden, omdat zij een substantieel aandeel hebben in de bevolking van die delen van Nederland waar we onderzoek naar doen (Noord-Nederland en de regio Rotterdam). Volledig of diepgravend is onze casestudy 
nog allesbehalve. Zoiets is binnen het bestek van dit artikel niet mogelijk, gegeven de omvang en de complexiteit van de problematiek.

\section{Een gestage stroom rapporten}

Autoriteiten die 'verhalen' in omloop brachten over bioscoopbezoek door Nederlandse gereformeerden waren er genoeg in lange jaren vijftig. De Generale Synode van Gereformeerde Kerken, de rijksoverheid en lokale instanties, ze deden allemaal een duit in het zakje. Typerend is dat hun verhalen vrijwel steeds gebaseerd waren op publieksonderzoek, ook al was het soms op een weinig wetenschappelijke manier. De aanleidingen liepen echter uiteen en ook de reikwijdte van de onderzoeken varieerde. De gereformeerde synode hield zich exclusief bezig met bioscoopbezoek door jongvolwassenen uit de eigen achterban, daarbij gedreven door de ambitie die achterban te beschermen tegen 'de ontstellende gevaren' van ongelimiteerd bioscoopbezoek en andere vormen van vrijetijdsbesteding die niet zouden passen bij een 'echt Christelijke levensstijl'. ${ }^{20}$ De rijksoverheid had aanvankelijk alleen oog voor wat in de media en daarbuiten bestempeld werd als de 'verwilderde massajeugd'. Deze jongeren, die grotendeels afkomstig waren uit de arbeidersklasse, zouden zich kenmerken door hun neiging tot vergaande individualisering en onmaatschappelijk gedrag, maar lieten verder qua religieuze achtergrond alle schakeringen zien die Nederland rijk was, van zeer streng belijdend tot onkerkelijk. In het onderzoek naar hun 'geestesgesteldheid' kreeg vrijetijdsbesteding, inclusief bioscoopbezoek, de nodige aandacht, omdat juist in die context de verwildering van deze jongeren zich nadrukkelijk manifesteerde, aldus de onderzoekers. ${ }^{21}$ Vanaf de tweede helft van de jaren vijftig was de interesse van de rijksoverheid voor bioscoopbezoek en andere vormen van vrijetijdsbesteding niet meer zo eenzijdig gericht op de jeugd en ook anders gemotiveerd. Bezorgdheid om de leeghoofdige vrijetijdsbesteding van de arbeidersjeugd maakte plaats voor een reflectie op de sturende rol van de overheid in een samenleving waarin de bevolking steeds meer vrijetijd kreeg. Om die reflectie op haar eigen rol en het eventuele beleid een stevige empirische basis te bieden, gaf minister van Onderwijs, Kunsten en Wetenschappen Jo Cals in I955 opdracht aan het Centraal Bureau voor de Statistiek door middel van een grootschalige survey zo veel mogelijk aan de weet te komen over de vrijetijdsbesteding van de Nederlanders. Deze survey vond plaats in de winter van I955-1956 en de uitkomsten ervan verschenen in de jaren I957-I959 in reeks van in totaal tien CBS rapporten. ${ }^{22}$ De eerste zeven waren gewijd aan steeds één specifieke vorm van vrijetijdsbesteding, waaronder de bioscoop (deel drie). De laatste drie stelden 'de invloed van een bepaald facet van de samenleving op diverse ontspanningsvormen' centraal. ${ }^{23}$ Deel negen was gewijd aan de invloed van de kerkelijke gezindte op de vrijetijdsbesteding en bevatte naast een analyse van de recreatiepatronen binnen de afzonderlijke confessionele groeperingen, ook een vergelijking tussen gelovige en seculiere Nederlanders.

Volgens de opstellers van het laatstgenoemde rapport lieten 'de cijfers omtrent het gereformeerde volksdeel het meest een typisch eigen levensstijl zien. ${ }^{24}$ Het sterkst onderscheidden de gereformeerden zich van andere Nederlanders waar het ging om 'die vormen van vrijetijdsbesteding, die door hen om principiële redenen worden afgewezen. ${ }^{25}$ De bioscoop 
hoorde daarbij en dus gingen gereformeerden daar aanmerkelijk minder naartoe dan overige gezindten. Wat nog niet wil zeggen dat zij van alle gezindten ook het felst tegen de bioscoop gekant waren. De leden van de Gereformeerde Bond binnen de Hervormde Kerk bij voorbeeld stelden zich doorgaans nog veel strikter op. ${ }^{26}$

Andere vormen van vermaak die door gereformeerden en de leden van de nog strengere protestantse kerken gemeden werden, waren theater, kaartspel en dansen. Daarentegen was de belangstelling voor kerkbezoek en lezen aantoonbaar groter dan onder de rest van de Nederlandse bevolking, evenals de deelname aan het religieuze en politieke verenigingsleven. In alle opzichten gaven orthodoxe protestanten de voorkeur aan vormen van recreatie 'met een zekere intellectuele inslag. ${ }^{27}$ En als men dan toch naar de bioscoop ging, dan liefst naar een film met een religieus thema. ${ }^{28}$ Dit typische recreatiepatroon was volgens het CBS verankerd in 'de centrale opvatting in de calvinistische levensbeschouwing, dat een intense beleving van de geloofswaarden op alle levensterreinen en dus ook op het gebied van de vrijetijdsbesteding, geboden is. ${ }^{2} 9$

Tegelijkertijd toont het CBS-rapport dat het taboe op bioscoopbezoek aan het verslappen was. ${ }^{30}$ Steeds meer gereformeerden gingen zo nu en dan naar de film: gemiddeld drie per keer jaar (het landelijke gemiddelde lag op acht keer per jaar). De meeste fervente bioscoopgangers onder de gereformeerden waren de ongehuwden in de leeftijdscategorie van I8 tot 28 jaar - een levensfase waarin ouders steeds minder controle hadden over het doen en laten van hun kinderen, zeker als deze een eigen inkomen hadden. ${ }^{3 \mathrm{I}}$ Leeftijd en burgerlijke staat waren niet de enige variabelen die ertoe deden. Ook de beroepsgroep, de sociale positie en het geslacht van een lid van de Gereformeerde Kerk hadden invloed op de frequentie van het bioscoopbezoek. Mannen gingen vaker dan vrouwen naar de film, landarbeiders en boeren gingen heel weinig, terwijl leidinggevenden, welgestelden en loontrekkende middenstanders weer aanmerkelijk vaker in de bioscoop te vinden waren. Deze verschillen zien we voor een belangrijk deel ook terug bij andere groepen, maar nergens hadden gender en sociaaleconomische positie zo veel impact op het bioscoopbezoek als onder gereformeerden. ${ }^{32}$ Wat ook uitmaakte, was de 'gelegenheidsstructuur'. Een inwoner van een dorp of stad waar zich een bioscoop bevond, ging vaker naar de film dan iemand die daarvoor een eind moest reizen. 33 Dat gold voor alle Nederlanders, ongeacht gezindte of leeftijd, maar bij adolescenten en jong volwassenen uit het gereformeerde milieu werkte de afstand tussen huis en bioscoop veel minder ontmoedigend. Sterker: deze specifieke subgroep had juist een opmerkelijke voorkeur voor bioscopen die relatief ver van huis verwijderd waren. Daar liepen ze immers minder risico door familie en bekenden te worden betrapt bij het bezoek aan wat binnen het dominante gereformeerde discours nog steeds bekend stond als een plaats van de duivel, of in de woorden van menig lokale dominee: 'de kijkkast van Satan.'34

\section{Ver weg en soms in angst en beven}

De voorkeur van jonge gereformeerde bioscoopgangers om elders naar de film te gaan, bracht met zich mee dat voor hen bioscoopbezoek veel meer tijd kostte dan voor anderen, dat ze er veel 
grotere afstanden voor aflegden en dat ze er ook financieel meer in moesten investeren als ze met het openbaar vervoer van en naar de bioscoop reisden. Bovendien zijn er aanwijzingen dat soms ook collectief beraamde 'cover-up' manoeuvres onderdeel waren van hun handelingspraktijk. Dat laat zich bijvoorbeeld afleiden uit de mondelinge getuigenis van Henk Berg, eind jaren veertig, begin jaren vijftig als filmoperateur in dienst van de Excelsior reisbioscoop, die opereerde vanuit Rotterdam.

Elke zondag ging Berg in opdracht van zijn werkgever naar gebouw Courzand in het tuindorp Heijplaat op de zuidoever van de Nieuwe Maas om daar filmvoorstellingen te geven. Heijplaat was gebouwd door de RDM (Rotterdamse Droogdokmaatschappij) om er de werknemers van de naastgelegen RDM-scheepswerf te huisvesten. De RDM bleef daarna eigenaar van de meeste huizen en overige gebouwen in het dorp. Ook van Courzand, een multifunctioneel gebouw, dat onder andere beschikte over een ruime feestzaal met voorzieningen voor toneelvoorstellingen en filmprojectie. Volgens Berg trokken de voorstellingen van de Excelsior reisbioscoop er nooit veel bezoekers uit Heijplaat zelf. De RDM-arbeiders zagen Courzand als een 'tent' van de baas en ze vertikten het om daar hun vrije tijd en centen te besteden. Liever namen ze de veerboot over de Nieuwe Maas om zich te gaan vermaken in de Rotterdamse binnenstad. Maar de filmvoorstellingen in Courzand trokken wèl een ander, al even reislustig publiek: jongeren uit de grotendeels streng protestantse dorpen op het eiland IJsselmonde, het achterland van Heijplaat. Op zondag trokken drommen jongelui uit die dorpen per fiets naar Heijplaat, zogenaamd om er naar de kerk te gaan. Slechts enkele straten verwijderd van gebouw Courzand stond namelijk de gereformeerde Elim kerk. Maar volgens Henk Berg lieten de meeste van deze zondagsfietsers de kerk links liggen. Ze kwamen liever bij hem in gebouw Courzand naar de film kijken. Zolang er maar minimaal één uit de groep wèl naar de kerk ging om uit te vissen waarover de dominee preekte, hadden ze later thuis een tamelijk waterdicht verhaal om hun 'zondige' uitspatting mee te verhullen. 35

Berichten over het 'elders naar de film gaan' door jongeren zijn er uit alle gereformeerde regio's waar wel eens onderzoek is gedaan naar vrijetijdsbesteding. ${ }^{36}$ Deze berichten doen vermoeden dat er twee varianten bestonden van deze praktijk: een incidentele variant, waarbij men maar één keer, of slechts sporadisch naar een 'bioscoop op afstand' ging, en een variant waarbij bioscoopbezoek elders min of meer routine was. Het verschil lijkt dan samen te hangen met de wijze waarop het geloof werd gepraktiseerd: bewust en geëngageerd, of formalistisch en routinematig, zonder diepergaande reflectie.

De eerste variant komt naar voren uit een serie interviews die Herma Beuving in 2015 afnam voor haar masterscriptie over bioscoopbezoek onder gereformeerden in de periode I945-1965.37 Uit het relaas van al haar informanten kwam naar voren dat zij in hun jeugd het gereformeerde geloof bewust praktiseerden en opgroeiden in een sfeer waarin mijding van de bioscoop de norm was. Maar op een zeker moment waren ze toch zó benieuwd naar wat dat nu precies was, de bioscoop, dat ze er wel een keer naartoe wilden. Vaak ging dat stiekem, zoals Manda S. (geboren in I942) vertelde, die in de jaren vijftig opgroeide binnen de gereformeerde gemeenschap van Hardinxveld-Giessendam. Op een zondagmiddag besloot ze met een vriendinnetje een kerkdienst te verzuimen om naar de bioscoop te kunnen gaan: 
Stiekem in de bus en dan onder de bank duiken, zodat niemand van het dorp jou zag zitten. En dan naar Sliedrecht toe. En dan naar de bioscoop. Ik weet ook echt niet meer de film. Ik heb volgens mij met geknepen billen daar gezeten. [...] En dan... Dan zorgen dat je weer op tijd terug was, voordat de kerk, als de kerk uit was. En dan kijken of je niet iemand tegen kwam waaraan je kon vragen waar de dominee over gepreekt had. En dan thuis zeggen van 'Nou, de dominee heeft daar en daar over gepreekt.'38

Zeker als zo'n bioscoopexpeditie heimelijk plaatsvond, is met de verhalen erover vaak de herinnering aan angst verbonden. Angst voor ontdekking, maar ook angst voor wat er met je zou gebeuren als je in de bioscoop zou sterven, of als nèt op dat moment de Here Jezus zou terugkeren op aarde. Zouden dan niet hel en verdoemenis je deel zijn?39 Die angst moet zeker aan de eerste bioscoopervaringen van menig gereformeerde Nederlander een bijzonder aspect gegeven hebben, al helemaal waar dominees en ouderlingen er niet voor terugschrokken om - zoals in Rotterdam voorkwam bij het dicht bij het Centraal Station gelegen Arena - af en toe gingen posten in de buurt van de ingang van een bioscoop. $4^{\circ}$ Maar niet voor alle gereformeerde bioscoopbezoekers gold dit op dezelfde manier. Er waren bijvoorbeeld ook belijdende jongeren die van hun ouders toestemming vroegen en kregen om zelf maar eens te gaan onderzoeken wat een bioscoopvoorstelling inhield. Eén van Beuvings respondenten mocht als vijftienjarige zelfs naar een cowboyfilm die gekeurd was voor zestien jaar en ouder. Als 'de wereld van het Kwade' dan toch onderzocht moest worden, kon je beter maar meteen het maximale eruit halen, zo lijkt in dit geval de achterliggende filosofie te zijn geweest.4 ${ }^{\mathrm{I}}$

De routine-variant van het bioscoopbezoek op afstand wordt uitvoerig beschreven in het zogeheten Bronnenboek bij het in I953 uitgebrachte overheidsrapport over de maatschappelijke verwildering der jeugd. ${ }^{42}$ Ook in andere sociologische studies en in krantenartikelen met betrekking tot de vrijetijdsbesteding van protestantse jeugd vinden we aanwijzingen dat een deel van de gereformeerde jongeren regelmatig naar de bioscoop ging buiten de eigen woonplaats. Het verhaal van Henk Berg over het publiek van zijn zondagse filmvoorstellingen in gebouw Courzand wijst eveneens in die richting. ${ }^{43}$

Wat uit deze bronnen naar voren komt is allereerst het beeld dat de gewoonte om elders naar de bioscoop te gaan niet op zichzelf stond, maar paste in een bredere uitgaanspraktijk. Zo noteert een onderzoeker over de jeugd in Veenendaal, dat onderdeel uitmaakt van de 'Biblebelt':

Regelmatig naar de bioscoop gaan 'hoort' niet volgens de Veense opinie. Daarom gaan de jongelui vaak naar Ede of Wageningen, een enkele maal naar café of bioscoop, doch meestal om ook daar wat rond te fietsen, naar meisjes te kijken en om wat te 'beleven'.

In bijna alle rapporten die opgenomen zijn in het Bronnenboek wordt melding gemaakt van groepsgewijs rondhangen met andere jongens en meisjes. Het was een uitgaanspraktijk die sterk gebonden was aan het 'daten' en zich vooral afspeelde in de weekenden en op zomeravonden. Op de (brom)fiets of met de bus trok de jeugd er op uit en verzamelde zich op vaste plekken: ze lagen kletsend in de berm, wandelden wat heen en weer in het bos of op straat, 
troffen elkaar in een café of cafetaria. Ook het dansen was een populaire bezigheid en naast bioscoopbezoek de belangrijkste vorm van commercieel amusement waaraan deze jongeren deelnamen. Dit terwijl 'paardansen' helemaal uit den boze was in Gereformeerde kringen omdat het 'sexuele hartstochten' zou aanwakkeren. ${ }^{44}$ Zoals wij al eerder opmerkten, de routine-variant met haar rekkelijke houding ten opzichte van vrijetijdsbesteding ging doorgaans samen met een geloofsbeleving die zich laat karakteriseren als 'op de automatische piloot'. Dat gold dan niet alleen voor de bioscoopgangers, maar ook voor hun ouders. Zij maakten er niet echt een punt van als hun kroost zich elders ging vermaken op een manier die eigenlijk niet strookte met hun religieuze overtuiging. Zo lang ze dit maar deden buiten het zicht van de gemeenschap waarin ze woonden, had niemand er last van.

Opvallend is verder dat er soms forse afstanden werden afgelegd om vermaak te vinden. Dat gold bijvoorbeeld voor de stappende jongeren uit Ooltgensplaat, een klein dorp op de uiterste oostpunt van het eiland Goeree-Overflakkee, waar de streng-orthodoxe stromingen binnen de gereformeerde geloofsgemeenschap veel aanhang hadden. De dichtstbijzijnde en meest bezochte uitgaanscentra waren voor de plaatselijke jeugd Oude Tonge en Middelharnis, respectievelijk tien en ruim zeventien kilometer westwaarts. Sommigen gingen ook geregeld naar Hellevoetsluis, dat hemelsbreed een kleine dertig kilometer verwijderd lag van hun eigen dorp en bovendien op de andere oever van het Hollands Diep. Wie er vanuit Ooltgensplaat naartoe wilde, moest eerst met het openbaar vervoer of de fiets naar Middelharnis en dan nog eens een flink eind varen met een veerboot. Je was dan al gauw een anderhalf uur onderweg. 45

De casus Ooltgensplaat laat ook zien hoe in plattelandsregio's met een hoofdzakelijk protestantse bevolking een specifieke infrastructuur van vertoningsplaatsen ontstond, die afgestemd was op de beperkte vraag naar film. Typerend voor deze zalen was dat ze meestal alleen in het weekend als bioscoop fungeerden. ${ }^{46}$ Zo ook in Middelharnis, waar filmliefhebbers vanaf december I946 wekelijks terecht konden in het Meyer Theater. Behalve voor filmvertoningen werd deze zaal, een annex van het ernaast gelegen hotel Meyer, gebruikt voor theatervoorstellingen, gymnastiekuitvoeringen, concerten, modeshows, en dergelijke. Eigenaar was in de jaren ' 40 en vroege jaren '50 Klaas Kaptein, die samen met zijn broer Adri zelf de
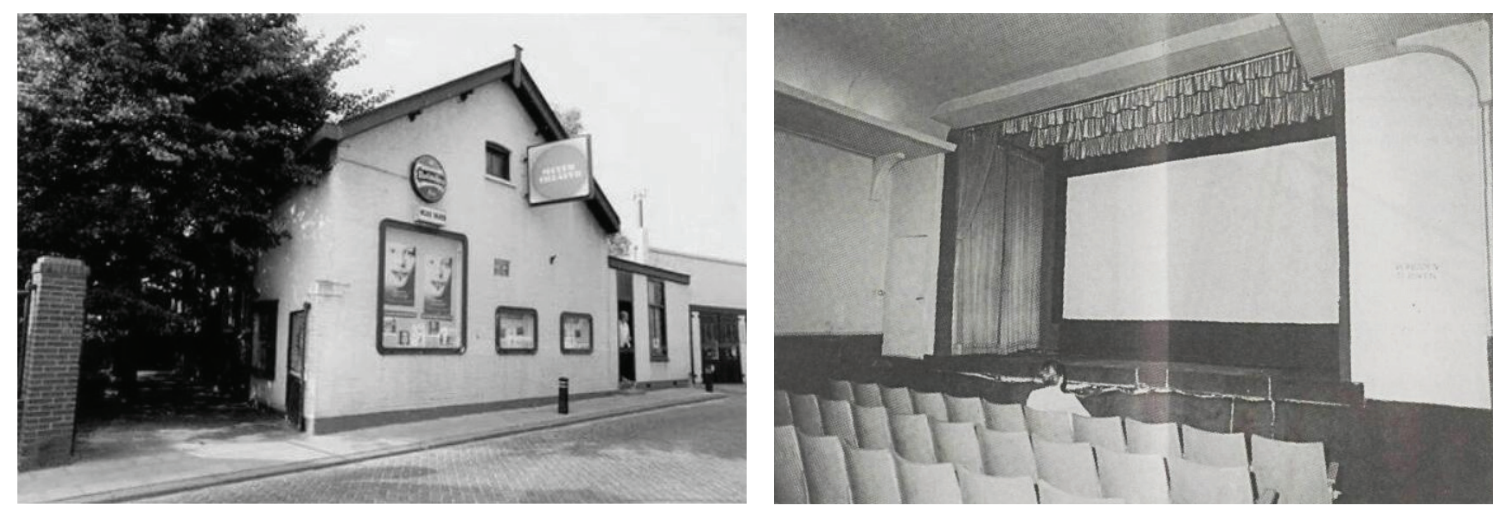

Het Meyer Theaterin Middelharnis. Geopend 13 december 1946, gesloten per1 november1999. Bron:Eilanden-Nieuws, 11 november 2005 . 
filmprojecties verzorgde. ${ }^{47}$ Dat deden ze trouwens niet alleen in Middelharnis, want als nevenbedrijf exploiteerden ze tevens een reisbioscoop. Vanaf I952 draaiden ze hun films ook geregeld in het Nederlands Hervormde Verenigingsgebouw Diakonia in Oude Tonge. Wat voor hun klanten uit Ooltgensplaat een stuk dichterbij, maar toch nog steeds geruststellend ver genoeg van huis was.

Nog een paar laatste vragen in relatie tot Ooltgensplaat - vragen die betrekking hebben op de factor tijd. Hoe ver terug in het verleden ging dat ver-van-huis-naar-de-film-gaan op oostelijk Goeree-Overflakkee? Was het een naoorlogs fenomeen of trokken Ooltgensplaters voor de oorlog bijvoorbeeld ook al naar Middelharnis om films en toneelvoorstellingen te zien in wat destijds nog simpelweg 'de zaal van Meyer' heette? Gingen ze misschien al langer naar de stad of een dorp verderop om een café te bezoeken zonder gezien te worden? En was dat reizen over lange afstanden om iets te kopen - een dienst of product - niet simpelweg een logisch onderdeel van het consumptiegedrag van bewoners van afgelegen gebieden, waarop religieuze achtergrond wel een versterkend effect kon hebben, maar zeker niet allesbepalend was? We weten het niet precies. $4^{8}$ Wat we wel weten is dat het relevant is dit soort brede vragen te stellen om een beter inzicht te krijgen in de factoren die bepalend waren voor de filmcultuur binnen een specifiek milieu.

Relevant is eveneens om nauwkeuriger in kaart te brengen welke variaties in vrijetijdsbesteding er bestonden binnen en tussen gezindten, zeker na de Tweede Wereldoorlog toen er op dat vlak van alles begon te veranderen. Uit de voorafgaande casus, hoe beperkt en schetsmatig deze ook is, blijkt al dat zelfs binnen het gereformeerde milieu uiteenlopende praktijken bestonden als het ging om bioscoopbezoek. En wellicht was dat ook wel zo in het katholieke milieu. Bovendien was er sprake van overlappende uitgaanspraktijken tussen de verschillende gezindten. Op basis een zeer gedetailleerde analyse van de gegevens uit de survey van I955-1956, concludeerden de CBS-onderzoekers bijvoorbeeld dat bij alle gezindten de frequentie van het bioscoopbezoek lager lag bij mensen die trouw naar de kerk gingen. Het effect was

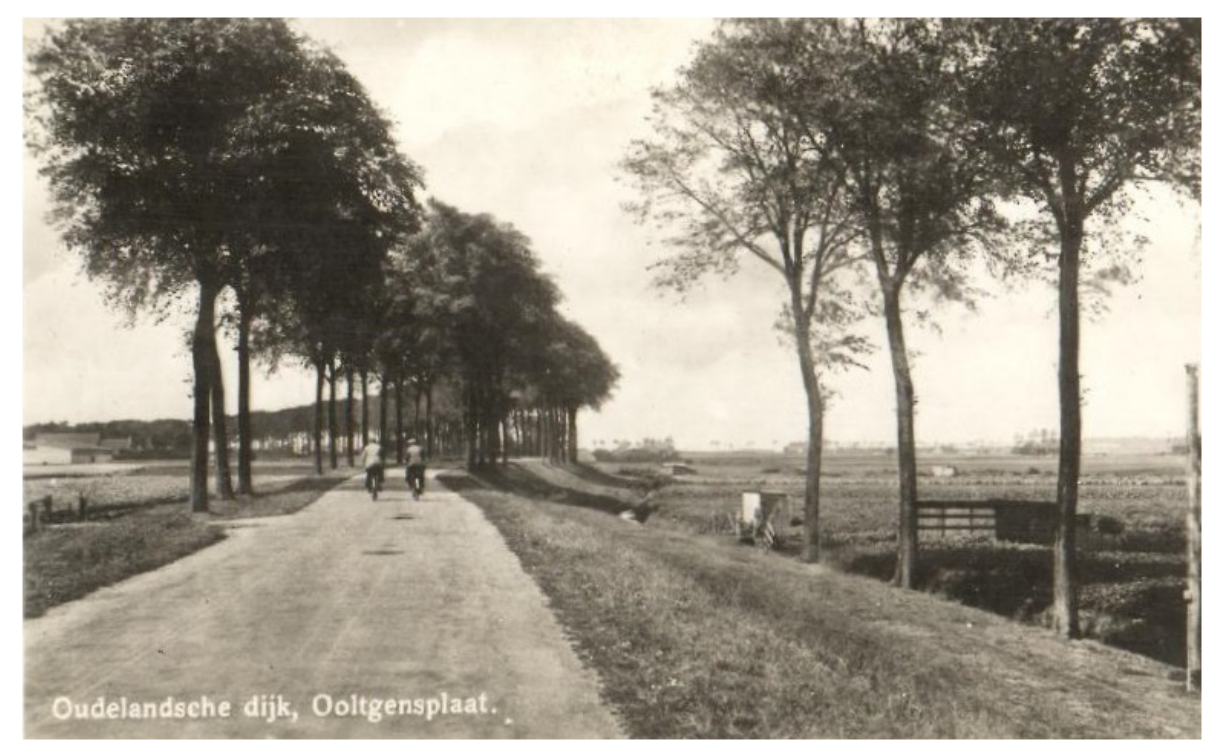

De weg naar Van Ooltgensplaat naar Oude Tonge en Middelharnis, circa 1950. Ansichtkaart, collectie J. Thissen. 
het sterkst bij de kerkgaanden onder de Nederlands hervormden: zij vertoonden als het ware gereformeerd gedrag. Het omgekeerde ging eveneens op. Niet-kerkse gereformeerden gedroegen zich 'niet weinig anders dan de dito hervormden' en zaten zelfs even vaak in de bioscoop (gemiddeld zeven keer per jaar). Kerksheid (wel/niet) bleek in dit opzicht zwaarder te wegen dan religieuze affiliatie. 49

\section{Verdeelde autoriteiten}

Wat het beeld nog een slag complexer maakt, is het feit dat tijdens de lange jaren vijftig de leiders van de Gereformeerde Kerken - in elk geval voor zover die behoorden tot de gereformeerde mainstream - met een zekere meegaandheid reageerden op het stijgende bioscoopbezoek van een deel van hun achterban, in het bijzonder de jeugd. Door dik en dun vasthouden aan het oude dogma der mijding leek hen een scenario dat gedoemd was te mislukken. Ze verwachtten dat jongeren in de toekomst naar de bioscoop zouden blijven gaan. Dat was eveneens de inschatting van het CBS..$^{\circ}$ De Gereformeerde Synode vond het daarom verstandiger om te proberen het bioscoopbezoek actief aan te sturen door middel van filmeducatie en het opzetten van een eigen vertoningscircuit. De eerste stappen op weg naar dit beleid lagen besloten in de onderzoeken naar het vraagstuk van de vrijetijdsbesteding die vanaf I949 in opdracht van opeenvolgende gereformeerde synodes werden ingesteld en waarin het bioscoopbezoek in het bijzonder werd belicht. Al meteen uit het eerste onderzoek, waarvan de resultaten in 1952 gepresenteerd werden, kwam naar voren kwam dat het eigenlijk wel meeviel. Zeker, 'voor zeer velen was bioscoopbezoek geen contrabande meer,' maar de groep gereformeerden die geregeld naar de bioscoop ging, was nog steeds 'vrij klein'. ${ }^{51}$ Van de jongeren, die in december 1950 deelnamen aan de enquête die uitgezet was onder I8- en 22-jarigen, had iets minder dan de helft nog nooit een bioscoop bezocht. ${ }^{2}$ En voor verreweg de meesten van hen die wel eens naar de film gingen, bleef het iets incidenteels. Bovendien bestond er nog altijd een sterk ontwikkeld gereformeerd gezins- en clubleven, waarbinnen verreweg de meeste geënquêteerden hun vrije tijd doorbrachten. 'De vulling van de vrije tijd schijnt geen probleem van betekenis te zijn,' aldus de notulen van de slotzitting van de Generale synode. 53 Er hoefde geen zondvloed te worden gekeerd, de gereformeerde dijken leken goed stand te houden en dus was er de ruimte en het zelfvertrouwen om een beleid te ontwikkelen dat niet puur restrictief, maar juist proactief was in de hierboven geschetste zin.

Na nog meer onderzoek, nu toegespitst op de vraag hoe zo'n beleidslijn concreet viel in te vullen, zocht de synode van de gereformeerde kerken aansluiting bij de CEFA, de Christelijke Filmactie. ${ }^{54}$ Dit samenwerkingsverband van verschillende protestantse kerken bestond al sinds I946 en hield zich onder andere bezig met het organiseren van filmvoorstellingen voor het protestants-christelijke publiek buiten het kader van de reguliere bioscoop. Op GoereeOverflakkee had een en ander tot gevolg dat het Meyer Theater er af en toe concurrentie bijkreeg. Zoals op 27 april I957, toen in de gereformeerde kerk van Middelharnis als afsluiting van een jongerendag 's avonds de film Strijd om de top (Duitsland, I953) werd vertoond, een documentaire over een bergbeklimming in de Himalaya. 55 CEFA-films waren vaak documentaires, 
een genre waar de meeste protestanten minder moeite mee hadden dan met fictiefilms. Maar voor de echt strenge orthodoxen maakte het niets uit. Fictie of geen fictie, film was slecht - zelfs als de vertoning niet in een bioscoop plaatsvond. Daarom bood bijvoorbeeld de Stichting voor Huishoudelijke Voorlichting ten Plattelande haar 'propaganda-avond met of zonder film' aan. ${ }^{6}$ Zelfs instructieve schoolfilms wekten weerstand op. 'Film is film! ... 't is een voorportaal van de hel!', aldus een raadslid in Ooltgensplaat, die bezwaar maakte tegen het gebruik van films in het lager onderwijs. 57

Waar het orthodox-protestantisme domineerde, en dat was het geval op Goeree-Overflakkee, bleef het naar de film gaan een praktijk waar niet alleen afkeurend over gesproken en geschreven werd, maar ook actief tegen ten strijde werd getrokken. In Middelharnis en Oude Tonge bijvoorbeeld verzetten scherpslijpers in de plaatselijke politiek zich fel tegen elke poging om de extreem hoge vermakelijkheidsbelasting op filmvoorstellingen te verlagen. Tegelijkertijd bleven ze ervoor pleiten om zulke voorstellingen op zondagen volledig te laten verbieden, net als trouwens het dansen, cafébezoek en voetballen. ${ }^{8}$ Kortom: de landelijke synodale autoriteiten mochten dan wat toeschietelijker worden ten aanzien van film en bioscoop, lokaal en regionaal ging lang niet iedereen daar in mee.

Van een hecht eenheidsfront op institutioneel niveau was dus geen sprake meer na de Tweede Wereldoorlog. Vanuit het perspectief van het kerkvolk - in het bijzonder het jonge kerkvolk - zal het effect daarvan vooral geweest zijn dat zowel mentaal als praktisch de vrijheid om te wèl te gaan groeide. Zoals de Leeuwarder Courant in maart 1957 observeerde: 'De bioscoop is allerminst een nieuw verschijnsel; het is zelfs niet nieuw dat zij 't dorpspubliek naar de grotere centra lokt. Maar ' $t$ is wel iets van de laatste jaren, dat nu ook de jeugd van protestants-christelijke huize de bioscoop (graag) bezoekt.' Sterker, een bioscoopexploitant waarmee de krant sprak verklaarde dat 'de jongelui "fan rjochts"' (van rechts = uit streng protestantse kring) zijn beste klanten waren. 59

\section{De tweede helix}

We refereerden er al aan in de inleiding van dit artikel: Karel Dibbets had het graag over het DNA van de Nederlandse filmcultuur dat ontrafeld moest worden, een operatie waarvoor het benodigde materiaal zou zijn samengebracht in de Cinema Context database. Maar daarin vind je geen dienstregelingen van het openbaar vervoer; geen CBS-statistieken over de bevolkingssamenstelling of urbanisatiegraad; geen afbeeldingen, adressen of GPS-coördinaten van gebouwen waar door de kerk goedgekeurde films werden vertoond; geen passages uit oude onderzoeksrapporten van ministeries of synodes; geen herinneringen van kerkelijk opgevoede mensen die in hun jonge jaren al dan niet stiekem en in angst en beven stad en land afreisden om buiten het zicht van hun ouders te ontdekken wat de bioscoop te bieden had. In tegenstelling tot de informatie die opgeslagen is in de Cinema Context database, hebben dit soort bronnen slechts zelden direct betrekking op het bioscoopbedrijf en de films die vertoond werden. Toch is het wel degelijk informatie die nodig is om te begrijpen hoe de filmconsumptie van verschillende groepen Nederlanders in elkaar stak. Pas met dergelijke contextinformatie erbij is er een 
adequaat model te bouwen van het DNA van de Nederlandse filmcultuur als geïntegreerd geheel. Met wat er nu in de Cinema Context database zit, lukt dat nog niet. Als we de metafoor van Karel Dibbets aanhouden: Cinema Context biedt slechts één van de twee met elkaar verstrengelde schroeflijnen of helices die kenmerkend zijn voor de structuur van DNA. Namelijk de helix van de aanbodzijde van de filmcultuur. De tweede helix, die van de consumptiekant, moet er nog bij om echt te gaan begrijpen wat de twee helices met elkaar samen laten ontstaan, namelijk de Nederlandse filmcultuur als een zowel historisch als geografisch meervoudig gesitueerde en heterogene verzameling houdingen en praktijken.

Met het begrip milieu hebben we in dit artikel een stuk gereedschap willen aanbieden waarmee die tweede helix is op te bouwen. Het uiteindelijke resultaat daarvan zou een typologie kunnen zijn van houdingen ten aanzien van filmconsumptie en de daarmee samenhangende praktijken. Elk ervan beschreven als een model dat gegevens over verhalen, praktijken, institutionele en organisatorische kaders, over fysieke infrastructuren en de temporaliteit van de filmconsumptie op elkaar betrekt. Èn waarin wordt aangegeven op welke concrete bevolkingsgroepen dat model voor welk tijdvak van toepassing is.

Een aanzet tot zo'n typologische werkwijze leverde begin jaren '7o al eens Jan Hes, toen hij in het kader van zijn promotieonderzoek op het snijvlak van film- en godsdienstsociologie een

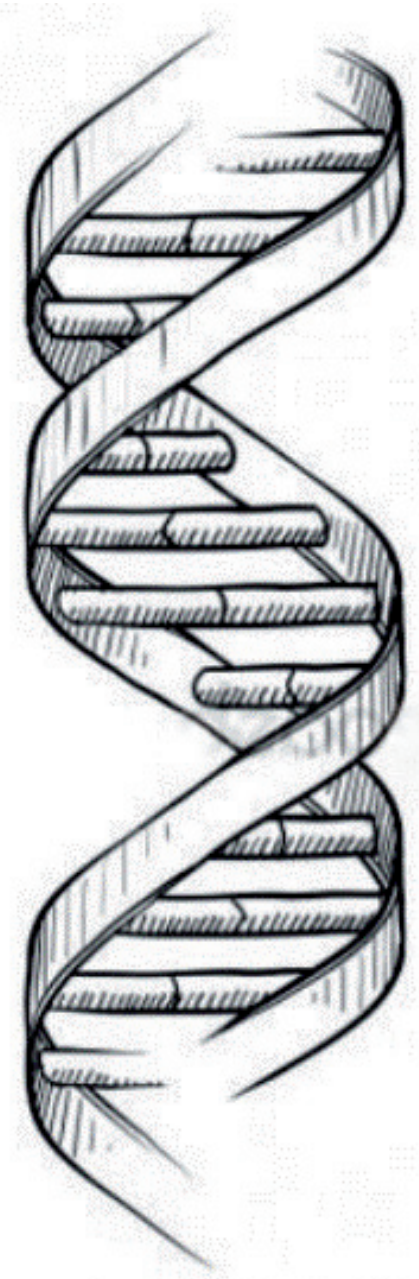

De dubbele helix-structuur van DNA. Bron: Canstockphoto. 
viertal religieus geïnspireerde grondhoudingen ten aanzien van film en bioscoop beschreef, die in de Nederlandse samenleving zouden voorkomen. ${ }^{60}$ Het door Hes gehanteerde perspectief is echter smaller dan wat ons voor ogen staat, omdat hij de religieuze factor centraal stelt. Er zijn ongetwijfeld ook milieus aan te treffen in de Nederlandse samenleving, waarbinnen de omgang met film niet of nauwelijks werd beïnvloed door de religieuze oriëntatie van mensen. Bovendien gaat het ons, als we het hebben over milieus, niet alleen of in de eerste plaats om mentale grondhoudingen. Er komt veel meer bij kijken. De vijf invalshoeken aan de hand waarvan we het onderzoek naar milieus willen structureren, maakten dat al duidelijk.

Zoals we al eerder aangaven, willen we met dit artikel vooral bereiken dat beoefenaren van de New Cinema History veel intensiever onderzoek gaan doen naar de bredere contexten waarin filmconsumptie is ingebed. Het gaat ons met name om de richting waarin het begrip milieu het onderzoek stuurt: naar buiten, centrifugaal, richting de context. In dat licht is het belangrijk ervoor te waken dat de centrifugale werking van het milieubegrip niet wordt afgezwakt door het óók te gaan gebruiken ter aanduiding van specifieke houdingen en praktijken ten aanzien van het medium film. Concreet: als we het hebben over de manier waarop gereformeerden omgingen met film en bioscoop, moeten we niet gaan spreken over zoiets als 'het gereformeerde filmmilieu'. Dit werkt ten eerste niet omdat in het gereformeerde milieu uiteenlopende houdingen en handelingspraktijken ten aanzien van film voorkwamen. Bovendien wordt het milieubegrip dan weer direct betrokken op film en filmconsumptie in engere zin. De exploratieve richting van het begrip wordt daarmee omgedraaid: van middelpuntvliedend naar middelpuntzoekend. En dan zijn we weer terug bij af.

Door de hierboven geschetste contextgerichte benadering kan de New Cinema History sterker dan tot nu toe aansluiting vinden bij de algemene geschiedwetenschap. We zullen daarvoor wel uit ons filmhistorische reservaat moeten komen. Wat prima is. Het helpt ons onderzoek relevanter te maken - niet alleen voor de collega's van geschiedenis, maar voor andere academische disciplines die zich bezig houden met sociaal-culturele problematieken. Wat dat betreft is dit artikel ook een antwoord op de vraag die Richard Maltby al ruim tien jaar geleden stelde in het Cinema in Context nummer van TMG: 'What would it take for cinema history to matter more? ${ }^{6 \mathrm{6I}} \mathrm{En}$ er is nog meer te winnen, ook vanuit ons eigen perspectief. Immers, de moderne geschiedwetenschap biedt in vergelijking met de New Cinema History een veel omvangrijker, diverser, en daarmee ook robuuster platform voor het ontwikkelen en bediscussiëren van zowel theoretische als methodologische perspectieven. ${ }^{62}$ Daarbij aansluiting te vinden, kan het onderzoek naar de DNA-structuur van de Nederlandse filmcultuur en de verdere ontwikkeling van de New Cinema History als geheel alleen maar ten goede komen.

\section{Noten}

I. Karel Dibbets, "Het taboe van de Nederlandse filmcultuur. Neutraal in een verzuild land," Tijdschrift voor mediageschiedenis 9, nr. 2 (2006): 46-64.

2. Dibbets, "Het taboe".

3. Judith Thissen en André van der Velden, "Klasse als factor in de Nederlandse filmgeschiedenis. Een eerste verkenning," Tijdschrift voor mediageschiedenis I2, nr. I (2009): 50-72; Clara Pafort-Overduin, John Sedgwick en 
Jaap Boter, "Explanations for the Restrained Development of the Dutch Cinema Market in the I930s," Enterprise Q Society, I3, nr. 3 (20I2): 634-67I. Zie ook Judith Thissen, "Understanding Dutch Film Culture: A Comparative Approach," Alphaville Journal of Film and Screen Media, 6 (Winter 2013), http://www.alphavillejournal.com/ Issue6/HTML/ArticleThissen.html (geen paginanummering).

4. Stefan Hradil, "Soziale Milieus - Eine praxisorientierte Forschungsperspektive," Aus Politik und Zeitgeschichte 44/45 (2006): 3. Zie ook Stefan Hradil, Sozialstrukturanalyse in einer fortgeschrittenen Gesellschaft: von Klassen und Schichten zu Lagen und Milieus (Opladen: Leske \& Budrich, I987).

5. Voor een recente beschouwing over de sociologische toepassing van het milieubegrip en de ontwikkeling daarvan, zie: Helmut Bremer en Andrea Lange-Vester Bremer, "Zur Entwicklung des Konzeptes sozialer Milieus und Mentalitäten," in Soziale Milieus und Wandel der Sozialstruktur. Die gesellschaftlichen Herausforderungen und die Strategien der sozialen Gruppen, red. Helmut Bremer en Andrea Lange-Vester (Wiesbaden: Springer, 20I4), I3-4I.

6. Hradil, "Soziale Milieus," 5.

7. Klaus Tenfelde, Proletarische Provinz: Radikalisierung und Widerstand in Penzberg/Oberbayern, 1900-1945 (München: R. Oldenbourg, I982). Zie ook: Gerhard Paul en Klaus Michael Mallmann, Milieus und Widerstand: eine Verhaltensgeschichte der Gesellschaft im Nationalsozialismus (Bonn: Dietz Nachfolger, 1995).

8. Zie bijvoorbeeld: Ralph Weiss, "Politisch-kommunikative Milieus. Notwendigkeit und Nutzen einer milieutheoretischen Analyse politischer Kommunikation," Medien Q Kommunikationswissenschaft 57, nr. I (2009): 3-22.

9. Voor een overzicht van begrippen en perspectieven zoals gehanteerd in de hedendaagse cultuurgeschiedenis, zie onder andere Peter Burke, What is Cultural History? (Cambridge en Malden: Polity, 2003) en Stefan Jordan, Theorien und Methoden der Geschichtswissenschaft, derde geactualiseerde oplage (Paderborn: Ferdinand Schöning, 20I6), hoofdstuk 7. Over het antagonisme tussen sociaal historici en een deel van de cultuurhistorici, zie onder meer: Brian Lewis, “The Newest Social History: Crisis and Renewal," in The Sage Handbook of Historical Theory, red. Nancy Partner en Sarah Foot (Los Angeles, Londen, New Dehli etc.: SAGE, 2013).

Io. Zie onder andere Jeffrey Klenotic, "Putting Cinema History on the Map: Using GIS to Explore the Spatiality of Cinema," in Explorations in New Cinema History: Approaches and Case Studies, red. Richard Maltby, Daniel Biltereyst en Philippe Meers (Chichester: Willey-Blackwell, 20II), 58-84; Åsa Jernudd en Mats Lundmark, "Cinemagoing in Sweden in the I940s: Civil Society Organizations and the Expansion of Rural Film Exhibition," in Cinema Beyond the City: Small-Town a Rural Film Culture in Europe, red. Judith Thissen en Clemens Zimmermann (Londen: Palgrave/BFI, 20I6), 67-86. Voor een breed overzicht, zie Julia Hallam en Les Roberts, red., Locating the Moving Image: New Approaches to Film and Place (Bloomington: Indiana University Press, 20I4).

II. Judith Thissen, "Understanding Dutch Film Culture.” Zie ook Daniel Biltereyst en Philippe Meers, "New Cinema History and the Comparative Mode: Reflections on Comparing Historical Cinema Cultures," Alphaville: Journal of Film and Screen Media II (20I6), http://www.alphavillejournal.com/Issueir.html.

I2. Zie ook Judith Thissen, "Cinema History as Social History: Retrospect and Prospect," in The Routledge Companion to New Cinema History, red. Daniel Biltereyst, Richard Maltby en Philippe Meers (te verschijnen 20I8).

I3. Voor concrete voorbeelden zie bijvoorbeeld André van der Velden en Judith Thissen, "Spectacles of Conspicuous Consumption: Picture Palaces, War Profiteers and the Social Dynamics of Moviegoing in the Netherlands, I9I4-I922," Film History 22 (2010): 452-46I en Judith Thissen, "Early Cinema and the Public Sphere of the Neighborhood Meeting Hall: The Longue Durée of Working-Class Sociability," in Beyond the Screen: Institutions, Networks and Publics of Early Cinema, red. Marta Braun et al. (Bloomington: Indiana University Press, 2012), 297-306.

I4. De aandacht voor temporaliteit en in het bijzonder ook voor de differentiaties en modaliteiten die zich daarin laten onderscheiden heeft in de sociale geschiedenis al een lange traditie (Braudel en navolgers). Dat ze ook in de mediageschiedenis verhelderend kunnen werken, is onlangs gedemonstreerd door Phillip Roberts. Phillip Roberts, "Building Media History from Fragments: A Material History of Philip Carpenter's Manufacturing Practice," Early Popular Visual Culture I4, nr. 4 (20I6): 319-339. Overigens zijn er al eerdere voorbeelden van te vinden in het werk van theaterhistorici. Zie bij voorbeeld: Frank Peeters, Jan Oscar de Grupter en het Vlaamse Volkstoneel 1920-1924. Een theaterhistoriografische studie. (Antwerpen: Peeters Publishers, I989).

I5. Voor een uitvoerig overzicht, zie: Hans Knippenberg, De religieuze kaart van Nederland. Omvang en geografische spreiding van de godsdienstige gezindten vanaf de Reformatie tot heden (Assen/Maastricht: Van Gorcum, I992). Midden jaren '50 stond circa 7\% van de Nederlanders geregistreerd als lid van de GKN en iets meer dan 50\% als lid van de NHK (waaronder ook de Gereformeerde Bond viel). Knippenberg, De religieuze kaart, 98 en Io7. Het merendeel van de protestantse kerkgenootschappen zijn sinds 2004 opgegaan in de Protestantse Kerk in Nederland (PKN). 
I6. Door de opening van nieuwe bioscopen in de kleinere steden en grotere dorpen steeg het bioscoopbezoek in de provincie sterk, in het bijzonder op het platteland. Vanaf I959 daalde in het gehele land het bioscoopbezoek in hoog tempo. In de grote steden liep de belangstelling al eerder terug. De branche zag de sterke daling nauwelijks aankomen. In vele plaatsen in de provincie werden tijdens de eerste jaren van de crisis nog nieuwe bioscopen geopend. Karel Dibbets, “Bioscoopketens in Nederland: Economische concentratie en geografische spreiding van een bedrijfstak, I928-1977” (doctoraalscriptie, Universiteit van Amsterdam, I980), 6I-64, 84-86.

I7. Centraal Bureau voor de Statistiek, Vrije-tijdsbesteding in Nederland. Winter 1955/'56. Deel 3: Bioscoopbezoek, in het bijzonder hoofdstuk IV.

I8. Joop Ellemers, "De jaren vijftig in Nederland," in Jaarboek mediageschiedenis 7, de jaren vijftig, red. Karel Dibbets et al. (Amsterdam: Stichting Mediageschiedenis, I995), 2I.

I9. Zie over die tweeledige dynamiek ook: Hans Righart en Piet de Rooy, "In Holland staat een huis. Weerzin en vertedering over 'de jaren vijftig'," in Een stille revolutie? Cultuur en mentaliteit in de lange jaren vijftig, red. Paul Luykx en Pim Slot (Hilversum: Verloren, I995), II-I8.

20. H. van Alkemade-Kwakkelstein et al., Rapport van de deputaten der Generale Synode van 1949 voor 'De Vrije Tijdsbesteding' aan de Generale Synode van de Gereformeerde Kerken, samen te komen te Rotterdam in het jaar 1952 (z.p., I952), I-2.

2I. M.J. Langeveld, Maatschappelijke verwildering der jeugd; Rapport betreffende de geestesgesteldheid van de massajeugd (Staatsuitgeverij: Den Haag, I952). Voor een uitgebreide bespreking van het massajeugdonderzoek, zie: Frans Meijers en Manuela du Bois-Reymond, "Het massajeugdonderzoek - inleiding” in Op zoek naar een moderne pedagogische norm. Beeldvorming over de jeugd in de jaren vijftig: het massajeugdonderzoek (1948-1952), red. Frans Meijers en Manuela du Bois-Reymond (Amersfoort/Leuven: Acco, I987), 20-38.

22. Centraal Bureau voor de Statistiek (CBS), Vrije-tijdsbesteding in Nederland. Winter 1955/'56. Tien delen (Zeist: W. de Haan, I957-I959).

23. CBS, Vrije-tijdsbesteding. Deel 9, voorbericht (zonder paginanummer).

24. Ibidem, I4.

25. Ibidem.

26. Zie in dit verband: J.E. Post, Gereformeerd zijn en blijven, een wankel evenwicht?! Een historisch-sociologisch onderzoek naar de ontwikkelingen van de Gereformeerde Kerken in Nederland, de Gereformeerde Bond in de Nederlandse Hervormde Kerk en de Christelijke Gereformeerde Kerken in de twintigste eeuw (Heerenveen: J.J. Groen en Zoon, I998).

27. CBS, Vrije-tijdsbesteding. Deel 9, I4.

28. CBS, Vrije- tijdsbesteding. Deel 3, 54. Hierbij moet worden aangetekend dat de bevindingen van de onderzoekers ten aanzien van de gereformeerde voorkeur voor films met een religieus thema misschien vertekend waren. Op het moment dat het veldwerk plaatsvond draaide in Nederland namelijk de film Martin Luther (West-Duitsland/ VS, I953), die zeer positieve kritieken gekregen had in de conservatief protestantse pers.

29. CBS, Vrije-tijdsbesteding. Deel 9, I4-I5. De onderzoekers tekenden aan dat het geschetste beeld waarschijnlijk enigszins vertekend was door een over-representatie van ultraorthodoxe respondenten in de steekproef. Een 'niet te verwaarlozen minderheid' van de als gereformeerd opgenomen respondenten zou de facto zou hebben behoord tot de kleinere gereformeerde kerken, die nog strenger waren dan algemeen gereformeerden, waartoe het onderzoek zich eigenlijk had moeten beperken. Ibidem, I5.

30. Ook de onderzoeken die uitgevoerd werden in opdracht van de Synode der Gereformeerde Kerken wijzen in die richting. Zie met name Van Alkemade-Kwakkelstein et al., Rapport van de deputaten der Generale Synode van 1949 en E.D. Kraan et al., Rapport van de deputaten der Generale Synode van de Gereformeerde Kerken in Nederland te Leeuwarden in 1955/56, benoemd voor de bestudering van het film-en bioscoopvraagstuk, voor wat betreft de pastorale taak van de kerk: aan de Generale Synode dier kerken, die in 1957 te Assen hoopt samen te komen (z.p., I957).

3I. CBS, Vrije-tijdsbesteding. Deel 9, 27-28.

32. CBS, Vrije-tijdsbesteding. Deel 9, 22, 27-28, 3I-32.

33. CBS, Vrije-tijdsbesteding. Deel 3, 32, 34 .

34. "Weer de film," Eilanden-nieuws. Christelijk streekblad op gereformeerde grondslag, 21 april I948. Zie ook R. Schippers, De gereformeerde zede (Kampen: J.H. Kok N.V., I955), I7I; Joh. C. Francken, Veel vragen ... één antwoord (Kampen: J.H. Kok N.V., I940), 242-243.

35. Interview met Henk Berg door André van der Velden, 26 maart 2013. 
36. Zie in het bijzonder M.J. Langeveld, Bronnenboek. Bevattende gegevens ten grondslag liggend aan rapport maatschappelijke verwildering der jeugd ('s-Gravenhage, Staatdrukkerij, I953) aldaar I57-I59 (over Stolwijk), I75-I76 (over Ede), 206 (over Veenendaal), 27I (over Ureterp), 286 (over Harkema-Opeinde).

37. Herma Beuving, “'Dat was een filmhuis. En je moest naar Gods huis.' Herinneringen aan de bioscoop, de film en het gereformeerde verzet tegen 'de wereld' in naoorlogs Nederland” (MA-scriptie, Universiteit Utrecht 20I5).

38. Beuving, "Dat was een filmhuis," I8. Sliedrecht ligt op een goede vijf kilometer van Hardinxveld-Giessendam en was per bus in een klein kwartier te bereiken.

39. Ibidem, I4, 44, 58 .

40. Ibidem, I9. De informant noemde Roxy als naam van de betreffende bioscoop, maar in de betreffende periode was die naam al veranderd in Arena, ook al leefde de naam Roxy in Rotterdam nog wel voort in de herinnering. Voor gereformeerde ouderlingen die posteren voor de ingang van bioscopen, zie ook "Bioscoop oefent niet steeds een invloed ten goede uit," Leeuwarder Courant, 2 maart I957.

4I. Beuving, "Dat was een filmhuis," 26.

42. M.J. Langeveld, Bronnenboek. Dit bronnenmateriaal moeten we overigens met de nodige omzichtigheid hanteren, aangezien al direct na de publicatie ervan geprotesteerd werd tegen de tendentieuze toon en tekortschietende objectiviteit van de inhoud van de rapporten. Niet alleen door wetenschappers en journalisten, maar ook door een deel van de burgers die in het Bronnenboek beschreven werden. Meijers en Du Bois-Reymond, "Het massajeugdonderzoek," 36-37. Voor reacties van journalisten en burgers, zie bij voorbeeld: "Materiaal te oud en te eenzijdig, zeggen acht bevoegde Ureterpers," Leeuwarder Courant, I5 augustus I953 en "Harkema vraagt in plaats van woorden nu eens daden van de overheid," Leeuwarder Courant, I9 augustus I953.

43. Hoewel uitgebreider oral history onderzoek nodig is, lijkt het er op dat het 'elders naar de bioscoop gaan' een troop is in de jeugdherinneringen van babyboomers uit streng-protestantse milieus. Telkens als we over ons onderzoek vertellen duiken er nieuwe anekdotes op met een vergelijkbare strekking.

44. CBS, Vrije-tijdsbesteding. Deel 9, 40; Van Alkemade-Kwakkelstein et al., Rapport van de deputaten der Generale Synode van 1949, 54 .

45. Tram- en autobusdiensten Goeree en Overflakkee I953/54 en I958/59, collectie RTM-Museum Ouddorp.

46. Weekendbioscopen waren een wijdverspreid fenomeen op het platteland, zie Thunnis van Oort, "Coming up this Weekend': Ambulant Film Exhibition in the Post-War Netherlands," in Cinema Beyond the City, I54-I57; Judith Thissen, "Multifunctional Halls and the Place of Cinema in the European Countryside, I920-I970," CiNéMAS - Journal of Film Studies 27, nr. 2-3 (20I7): 9I-III.

47. "Meyer Theater blijft behouden,"Eilandennieuws.nl, II september 20I7, geraadpleegd 20 december 20I7; Aanvullende data: www.cinemacontext.nl.

48. Uit een eerste verkennend krantenonderzoek kwam naar voren dat verhalen over het bewust verkiezen van vertier buiten de eigen woonplaats ook over de Friese plattelandsjeugd circuleren, maar we vonden tot nu toe geen aanwijzingen voor een vergelijkbaar recreatiepatroon in Noordoost-Groningen en ruraal Limburg. Met andere woorden, het type woonomgeving (stedelijk versus platteland) lijkt niet de doorslaggevende factor.

49. CBS, Vrije-tijdsbesteding. Deel 3, 54-55. Ook de steekproef over de vrijetijdsbesteding van gereformeerde jongeren, uitgevoerd in 1950 in opdracht van de Generale Synode van Gereformeerde Kerken, laat een sterke correlatie zien tussen kerkgang en bioscoopbezoek. De onderzoekers concludeerden dat de 'bioscoopbezoekers overwegend slechtere kerkgangers' waren en dat dit onderscheid ook gold voor hen die soms naar de bioscoop gingen (in tegenstelling tot nooit). Onder de gereformeerden jongeren die als regels hoogstens eenmaal in de week naar de kerk gingen, waren naar verhouding meer bioscoopbezoekers dan onder hen die tweemaal gingen. Van Alkemade-Kwakkelstein et al., Rapport van de deputaten der Generale Synode van 1949, 43.

50. CBS, Vrije-tijdsbesteding. Deel 3, 53 .

5I. Acta van de Slotzitting van de Generale Synode van 's-Gravenhage en van de Generale Synode van Rotterdam 1952 en 1953 van de Gereformeerde Kerken in Nederland gehouden te 's-Gravenhage op woensdag 14 juni 1950 en te Rotterdam van 26 augustus -6 november 1952 en van 5 januari -16 januari 1953 (J.K Kok: Kampen, I954), 55.

52. Van Alkemade-Kwakkelstein et al., Rapport van de deputaten der Generale Synode van 1949, 54. Het betreft alleen ongehuwde jongeren.

53. Acta van de Slotzitting van de Generale Synode van 's-Gravenhage en van de Generale Synode van Rotterdam 1952 en 1953, 55.

54. Jan Hes, In de ban van het beeld: een filmsociologisch-godsdienstsociologische verkenning (Assen: Van Gorcum, I972), I27-I28. Zie ook: Rapport van de deputaten der generale synode van de Gereformeerde Kerken in Nederland te Leeuwarden in 1955/56. 
55. Advertentie Gereformeerde Kring Ring Flakkee, Eilanden-nieuws, 26 april 1957.

56. Zeeuws Landbouwblad, 24 december i965, p. Io.

57. "De raad van Ooltgensplaat gaf grond uit voor particuliere bouw," Eilanden-nieuws, I2 april I952, p. 5.

58. "Bioscoop een gevaar voor de jeugd," Eilanden-nieuws, p. I; "Gemeenteraad Oude Tonge". Eilanden-nieuws, I8 september I954, p. 6. Zie ook “Vóór de keus!,” Eilanden-nieuws, 22 augustus i953, p. I.

59. "Bioscoop oefent niet steeds een invloed ten goede uit," Leeuwarder Courant, 2 maart I957.

6o. Hes, In de ban van het beeld.

6I. Richard Maltby, "On the Prospect of Writing Cinema History from Below," Tijdschrift voor mediageschiedenis 9, nr. 2 (2006): 85. Dit TMG-artikel verscheen een jaar later in een aangepaste versie waarin de nadruk verschoof van een methodische perspectief naar de centrale vraag hoe filmhistorisch onderzoek relevanter kon worden: Maltby, “How Can Cinema History Matter More?," Screening the Past 22 (2007), http://tweb.latrobe.edu.au/ humanities/screeningthepast/22/board-richard-maltby.html. Voor een discussie over de impact van deze publicaties op het veld van 'New Cinema History', zie Thissen, "Cinema History as Social History”.

62. Voor twee recente overzichten, zie Nancy Partner en Sarah Foot, red., The SAGE Handbook of Historical Theory (Los Angeles, etc: SAGE, 20I3) en Stefan Jordan, Theorien und Methoden der Geschichtswissenschaft 3, aktualisierte Auflage (Paderborn: Ferdinand Schöningh, 2016).

\section{Biografie}

Judith Thissen is universitair hoofddocent filmgeschiedenis aan de Universiteit Utrecht bij het departement Media en Cultuurwetenschappen. Haar onderzoeksinteresses liggen op het snijvlak van sociale geschiedenis en mediageschiedenis. Ze richt zich daarbij vooral op de rol van bioscoopcultuur in moderniseringsprocessen. Samen met Clemens Zimmermann redigeerde ze onlangs Cinema Beyond the City: Small-Town and Rural Film Culture in Europe (Palgrave/BFI, 20I6).

André van der Velden is als mediahistoricus verbonden aan het departement Media- en Cultuurwetenschappen van de Universiteit Utrecht. Hij doet onderzoek naar filmcultuur en theater tijdens het Interbellum. Op dit moment houdt hij zich vooral bezig met de ontwikkeling van het filmbedrijf in Rotterdam en de carrière van Abraham Tuschinski. 